\title{
Use of black carp (Mylopharyngodon piceus) in biological control of intermediate host snails of fish-borne zoonotic trematodes in nursery ponds in the Red River Delta, Vietnam
}

Nguyen M Hung ${ }^{1}$, Nguyen $V$ Duc ${ }^{1}$, Jay R Stauffer $\mathrm{Jr}^{2}$ and Henry Madsen ${ }^{3^{*}}$

\begin{abstract}
Background: The risks of fish-borne zoonotic trematodes (FZT) to human health constitute an important problem in Vietnam. The infection of humans with these trematodes, such as small liver trematodes (Clonorchis sinensis and Opisthorchis viverrini), intestinal trematodes (Heterophyidae) and others is often thought to be linked to fish culture in areas where the habit of eating raw fish is common. Juvenile fish produced in nurseries are often heavily infected with FZT and since fishes are sold to aquaculture facilities for growth, control of FZT in these fishes should be given priority. Controlling the first intermediate host (i.e., freshwater gastropods), would be an attractive approach, if feasible. The black carp, Mylopharyngodon piceus, is a well-known predator of freshwater snails and is already used successfully for biological control of snails in various parts of the world including Vietnam. Here we report the first trials using it for biological control of intermediate host snails in nursery ponds stocked with 1-week old fry (10-12 mm in length) of Indian carp, Labeo rohita.
\end{abstract}

Methods: Semi-field and field experiments were set up to test the effect of black carp on snail populations. In the semi-field experiment a known quantity of snails was initially introduced into a pond which was subsequently stocked with black carp. In the field trial in nursery ponds, density of snails was estimated prior to a nursing cycle and at the end of the cycle (after 9 weeks).

Results: The results showed that black carp affect the density of snail populations in both semi-field and field conditions. The standing crop of snails in nursery ponds, however, was too high for 2 specimens to greatly reduce snail density within the relatively short nursing cycle.

Conclusions: We conclude that the black carp can be used in nursery ponds in Northern Vietnam for snail control. Juvenile black carp weighing 100 - 200g should be used because this size primarily prey on intermediate hosts of FZT and other studies have shown that it does not prey on fish fry of other species. It may be necessary to use a high stocking density of black carp or to reduce snail density in the nursery ponds using other measures (e.g. mud removal) prior to stocking fry in order for the black carp to keep the density of intermediate host snails at a very low level.

Keywords: Molluscivore fish, Clonorchis sinensis, Intestinal trematodes, Transmission, Aquaculture

\footnotetext{
* Correspondence: hmad@sund.ku.dk

${ }^{3}$ Centre for Health Research and Development, Department of Veterinary Disease Biology, Faculty of Health and Medical Sciences, University of Copenhagen, Thorvaldsensvej 57, Frederiksberg C 1871, Denmark Full list of author information is available at the end of the article
} 


\section{Background}

Liver and intestinal trematodes are important public health concerns in many Asian countries [1-3]. People become infected when they eat raw or insufficiently cooked fish containing the infective stage, metacercariae [4-6]. The pathology caused by liver trematode infections in people can be quite severe [2], while infections with intestinal trematodes generally are considered to be less severe [7].

Vietnam is endemic for small liver trematodes, Clonorchis sinensis (Cobbold, 1875) and Opisthorchis viverrini (Poirier, 1886), with an estimated 2 million people infected $[8,9]$. While there is no estimation of the number of people infected with intestinal trematodes, such as Haplorchis pumilio (Looss, 1886), Centrocestus formosanus Nishigori, 1924 and others, the prevalence is believed to be high, e.g. in the Red River Delta and some provinces in central Vietnam $[6,10,11]$.

Light infections by C. sinensis, O. viverrini or O. felineus (Rivolta, 1884) are asymptomatic, but high levels of infection and chronic infection cause damage to the bile duct epithelium, eliciting gastrointestinal problems, damage to the liver and possibly cholangiocarcinoma [2,12-14]. Opisthorchis viverrini and C. sinensis have been rated as class 1 carcinogens by the International Agency for Research on Cancer [15]. Lun et al. [16] estimated that 35 million people globally could be infected by $C$. sinensis, while more than 11 million people are infected with Opisthorchis spp. [17]. Epidemiology and pathogenesis of intestinal trematodes are not well understood. Compared to liver trematodes, infection with intestinal trematodes does not generally present significant clinical symptoms [7,12], however, some Heterophyidae species can cause significant pathology, often fatal, in the heart, brain and spinal cord of humans [18]. It is thought that approximately 18 million people could be infected globally by these species [5].

The trematodes not only cause pathology in the final hosts, they also adversely impact on the intermediate hosts. Trematode infection in snails reduces survival and reproduction $[19,20]$. Large numbers of Haplorchis pumilio cercariae can be lethal to fry of Oreochromis niloticus (Linnaeus, 1758) within a few hours [21] and high loads of Centrocestus formosanus metacercariae cause morbidity in their fish hosts [22], reducing their growth and increasing mortality. Presence of metacercariae in fish raised in aquaculture not only pose a health risk for people eating insufficiently cooked or raw fish, but it also reduce marketability of fish [23].

Aquaculture in northern Vietnam is to a large extent dependent on family-based integrated pond systems, the so-called VAC system where a garden (Vuon), a fish pond (Ao) and an animal shed (Chuong) constitute a functional unit. The VAC system is considered as an ecological way of using farm products in a natural cycle [24], which has been encouraged by the Vietnamese government and has had remarkable results from economic, health and nutrition perspective [25]. In this system, manure from the husbandry is used to fertilize ponds, so as to stimulate algal growth and subsequently fish growth, and remnants from garden products and fish remains can be fed to pigs/cattle. Mud from the ponds is used to fertilize gardens or fields [26]. In fish ponds, the main cultured fish are various carp species. Fish for seeding are produced in hatcheries and after about one week, fry is transferred to nursing ponds, where they will be kept for about 9 weeks before being sold for grow-out farmers. Previous studies have shown that fry leaving the hatcheries are free from infection with FZT [27], while transmission is intense in nursing ponds $[6,28]$ and grow-out ponds $[6,10,28,29]$.

Controlling the intermediate host snails should be part of an integrated strategy for control of these infections in fishes. Since nursery ponds are very important for the transmission it would be important to control infections in these ponds. Biological control of snails using molluscivorous fishes, such as the black carp, Mylopharyngodon piceus (Richardson, 1846), might be a viable option.

Black carp is a large cyprinid fish, with a maximum reported size of about $1.5 \mathrm{~m}$ and a weight of $70 \mathrm{~kg}$ [30]. The native range of black carp includes most major Pacific Ocean drainages of eastern Asia from the Amur River Basin to the West-Pearl River Basis and the Red River of northern Vietnam. Larvae and small juveniles feed almost entirely on zooplankton and aquatic insects while larger juveniles and adults feed mainly on molluscs [30]. The shift in diet occurs with the development of pharyngeal teeth at lengths from 3-33 cm, depending on the development rate of the fish and abundance of prey available [30]. The black carp is already used for biological control of snails in various parts of the World [30-35]. The major concern about using black carp outside its natural distribution is its potential spread to large rivers, where it may establish populations, with potential severe effect on native mollusc populations [30].

We attempted to use black carp in nursery ponds yet this could present a major challenge because the black carp used, should have an appreciable size compared to the fry, so that the fry are protected as the larger carp tend to consume the intermediate host snails (species of Thiaridae and Bithynidae). One concern about using black carp in nursery ponds is that it might switch diet from snails to the fry that they are supposed to protect from infection. Thus it has been observed that fish, which in their natural habitat are specialized molluscivores, will switch to a softer diet when introduced into ponds for biological control [36]. Hung [37] showed that juvenile black carp could be used in nursery ponds without affecting survival of fry or juvenile fishes. Disturbances to the pond 
environment caused by the black carp, however, might affect fry survival; for example suspension of bottom sediment in the water due to its feeding at the bottom. This paper describes two field trials using black carp to control intermediate host snails in (1) a pond without other fishes and (2) in real nursery ponds.

\section{Methods}

\section{Semi-field experiment}

An experimental pond $(20 \mathrm{~m}$ wide $\times 30 \mathrm{~m}$ long $\times 1.6 \mathrm{~m}$ deep) at The Research Institute for Aquaculture no. 1 (RIA 1), Tu Son, Bac Ninh was used in this trial from May to August, 2011. The pond was divided into 2 equal parts $15 \times 20 \mathrm{~m}$ by a net with a mesh size of $2 \times 2 \mathrm{~cm}$ across the pond. The mesh size allowed snails to pass from one area to the other, while black carp could not.

Five exclosures $(2 \times 1 \times 1.7 \mathrm{~m})$ with a mesh size of $2 \times 2 \mathrm{~cm}$ were established in each part of the pond. The exclosures were fixed to a bamboo pole in each corner and in each corner of the exclosure a brick was placed to ensure that the bottom part stayed covered by a $2-3 \mathrm{~cm}$ layer of bottom sediment. The water level in the pond was kept at $1.2 \mathrm{~m}$. A total of 12,763 thiarid snails primarily Melanoides tuberculata (Müller, 1774) and 6,479 viviparid snails - primarily Angulyagra polyzonata (Frauenfeld, 1862) were introduced into the pond over some days. The total weight of snails released evenly over the entire pond was $25 \mathrm{~kg}$. Thereafter, 5 specimens of black carp $(700-1500 \mathrm{~g})$ were released in one part of the pond and 10 specimens in the other part. After three months, the pond was emptied. Mud inside each exclosure was removed to a depth of $5 \mathrm{~cm}$ and sieved to retain snails, which were then counted. Next to each exclosure, mud was similarly removed and sieved from an area of the same size as the exclosure, i.e. $2 \mathrm{~m}^{2}$. All live snails were collected and counted. After that, the entire bottom of the pond was checked again to find any live snails. The black carp specimens were anesthetized before euthanization. All specimens were preserved in formalin and stomachs were later examined for content.

\section{Field trial in real nursery ponds}

Three households, which had two similar nursery ponds (size, depth and dense snail population), were selected in Hai Quang commune, Hai Hau district, in Nam Dinh Province. One pond in each household was selected (by flipping a coin) for stocking with black carp and the other would serve as its control. The surface area of the ponds ranged from $200(20 \times 10 \mathrm{~m})$ to 360 square meters $(20 \times 18 \mathrm{~m})$. Water was pumped into the ponds from a small canal (1-1.5 m wide) close to the pond. There was a crude filter preventing coarse material entering the pump but there was no filtering at the inlet tube to the pond, therefore some snails could have entered the pond during the process. Many farmers, however, use a filter on the inlet pipe [38], but the mesh size is not fine enough to prevent juvenile snails from entering the pond.

After filling, snail population density was estimated immediately before starting the experiment and again at termination, using a dredge $0.25 \mathrm{~m}$ wide mounted on a $3 \mathrm{~m}$ long handle [38]. The dredge was dragged from $2 \mathrm{~m}$ off shore perpendicularly back to the pond bank. Thus, the area sampled was $0.25 \times 2 \mathrm{~m}$ with a total of 6 such samples obtained from each pond. Each sample was washed and all live snails were counted and identified to species using keys by Thanh [39] and Brandt [40].

The experiment started in June, 2011 when 30,000 fry of Indian carp, Labeo rohita (Hamilton, 1882), were released in each of the 6 ponds. Two specimens of black carp (weight: 400 - 1100g) were released in the selected intervention pond in each household. After 9 weeks (the normal duration of the nursing period), the experiment was terminated and all Indian carp fingerlings were caught by seining and transported to another pond. Ponds were then emptied for water.

The density estimated by the dredge can probably only be considered as semi-quantitative and we therefore decided to evaluate this sampling method by quantitative sampling immediately after emptying the pond. The density of snails in the emptied ponds was measured by using an aluminium frame $(0.5 \times 0.5 \mathrm{~m})$ to sample the following distances from the pond bank along a transect perpendicular to the bank, $0-50 \mathrm{~cm}, 50-100 \mathrm{~cm}, 100-150 \mathrm{~cm}$ and $150-200 \mathrm{~cm}$. Mud was removed within the demarcated area to a depth of about $5 \mathrm{~cm}$ and sieved through a mesh $1 \times 1 \mathrm{~mm}$. These transects did not overlap those that were sampled using the dredge. All snails were counted.

The black carp recaptured were anesthetized, euthanized and preserved in $10 \%$ formalin for later examination of stomach content.

\section{Statistical analyses}

Counts of thiarid and viviparid snails were compared between treatments using negative binomial regression [41] specified in a generalized linear model with a log-link function. The ancillary parameter was estimated by full maximum likelihood estimation [41]. The effect of farm, depth, treatment and their interaction were included in the model as an explanatory variable. Differences with p-values below 0.05 were considered significant.

\section{Ethical considerations}

The experimental design was approved by the project review board at Institute of Ecology and Biological Resources, Vietnamese Academy of Science and Technology in April 2011. Fish were handled in accordance with the EU Directive 2010/63/EU for animal experiments http://eur-lex.europa.eu/LexUriServ/LexUriServ. 
do?uri=OJ:L:2010:276:0033:0079:EN:PDF. Farmers were promised financial compensation if the black carp against expectations significantly affected survival of fry during the nursing cycle.

\section{Results}

\section{Semi-field experiment}

No live snails were found in the part of the pond with 10 black carp specimens, while in the other part with 5 specimens, 20 snails ( 8 specimens of Thiaridae and 12 specimens of Viviparidae) were found inside the exclosures and only 1 specimen of $A$. polyzonata was found outside exclosures. These numbers of snails obviously are too low for statistical analysis. The entire pond bottom was scattered with shell fragments and broken shells.

Stomachs of these black carp specimens were all empty, which was to be expected as the population of snails had been almost eliminated.

\section{Field trial in nursery ponds}

The pre-intervention snail sampling from the 6 ponds combined revealed a total of 520 specimens of the Thiaridae, including 497 specimens of $M$. tuberculata plus 23 specimens of Thiara scabra (Müller, 1774) and 971 specimens of the Viviparidae, including 925 individuals of A. polyzonata and 46 specimens of S. aeruginosa (Reeve, 1863). In addition, 21 specimens of Pomacea canaliculata (Lamarck, 1819) (Ampullaridae) were found. Bithynidae (e.g. Bithynia fuchsiana (Moellendorff, 1888) and Parafossarulus manchouricus (Benson, 1842) were not found.

At pre-intervention, counts of thiarid snails (Figure 1) varied significantly among farms $(\mathrm{p}<0.001)$, but densities between the two ponds within farms did not differ except in farm 3 where density of thiarid snails in the pond used for black carp was 2.24 times that in the control pond. Viviparid counts differed significantly among farms ( $p<0.001)$ but did not differ between control and intervention ponds in any of the three farms. The total snail count varied among farms $(\mathrm{p}<0.01)$ and was 1.80 times higher in the pond for black carp in farm 3 than in the corresponding control pond.

At the end of the nursing cycle, Bithynia fuchsiana was recorded from three ponds (8 specimens in total). At post-intervention, counts of thiarid snails varied significantly among farms $(\mathrm{p}<0.001)$, while differences between control and intervention ponds was significant only in farm 3; i.e. counts in the pond with black carp was 0.36 times that in the control pond ( $\mathrm{p}<0.001$ ). Viviparid counts differed among farms $(\mathrm{p}<0.05)$ and was lower in the ponds with black carp than in the corresponding control ponds i.e. count ratios were 0.87 (not significant), $0.39(\mathrm{p}<0.001)$ and $0.33(\mathrm{p}<0.001)$ in farms 1, 2 and 3, respectively. For the total snail counts the pattern was similar to that for the viviparid snails alone, i.e. counts in black carp ponds were 0.89 (n.s.), $0.48(\mathrm{p}<0.001)$ and $0.36(\mathrm{p}<0.001)$ times that in control ponds in farms 1, 2 and 3, respectively.

On average, counts of thiarid snails at pre-intervention was higher in ponds with black carp than in control ponds (count ratio: 1.42, $\mathrm{p}<0.01$ ) and on average counts in control ponds at termination were $1.63(\mathrm{p}<0.05)$ times those in control ponds at the beginning, showing that density increased during the nursing cycle. At termination, counts of thiarid snails in black carp ponds were on average 0.65 of those in the control ponds, but that was about the same as in the control ponds at the beginning (count ratio $=0.98$, n.s.), showing that density of thiarid snails declined in black carp ponds. Counts of viviparid snails in black carp ponds were on average 0.87 times that in control ponds at the beginning of the experiment. At termination, the counts in control ponds were $2.67(\mathrm{p}<0.001)$ times higher than at the beginning, while in black carp ponds, the viviparid counts on average were 0.46 times the counts in control ponds (Figure 1) and that corresponded to 1.24 times the counts in control ponds in the beginning. Thus on average viviparid density increased in both control and black carp ponds during the nursing cycle, but to a lesser extent in black carp ponds than in control ponds..

\section{Density of snails}

The quantitative sampling in the emptied pond showed that the dredge sampling underestimated the density (Figure 2). Density of viviparid snails after adjusting for differences among ponds varied significantly with distance from the shore $(\mathrm{p}<0.001)$; it was highest close to the shore $(0-0.5 \mathrm{~m})$ and densities in sections $0.5-1.00 \mathrm{~m}, 1.00-1.50 \mathrm{~m}$ and $1.50-2.00 \mathrm{~m}$ respectively were $0.69,0.37$ and 0.24 of that closest to the shore. The same figures for thiarid snails were $0.81,0.63$ and 0.51 , respectively.

We attempted to use these densities to calculate a very rough estimate of the standing crop of snails in each pond. Since the pond bottom only sloped slightly beyond $2 \mathrm{~m}$ from the shore, average density of samples taken $1.5-2.0 \mathrm{~m}$ from the shore was assumed to be the density for the middle part of the pond (distance $>2 \mathrm{~m}$ from the shore), while the mean of the $6^{*} 4$ samples was used as density of the section up to $2 \mathrm{~m}$ from the shore. From several samplings representing the total size variation we have estimated an average wet weight of $0.38 \mathrm{~g}$ per snail for thiarid snails and $1.5 \mathrm{~g}$ for viviparid snails. Thus the estimated weight of thiarid snails ranged from $0.8 \mathrm{~kg}$ to $13.6 \mathrm{~kg}$ and viviparid snails ranged from 8.6 to $58.8 \mathrm{~kg}$ in these ponds. Total snail weight ranged from 11.3 to $56.8 \mathrm{~kg}$. The estimated maximum consumption by black carp during the entire period would 

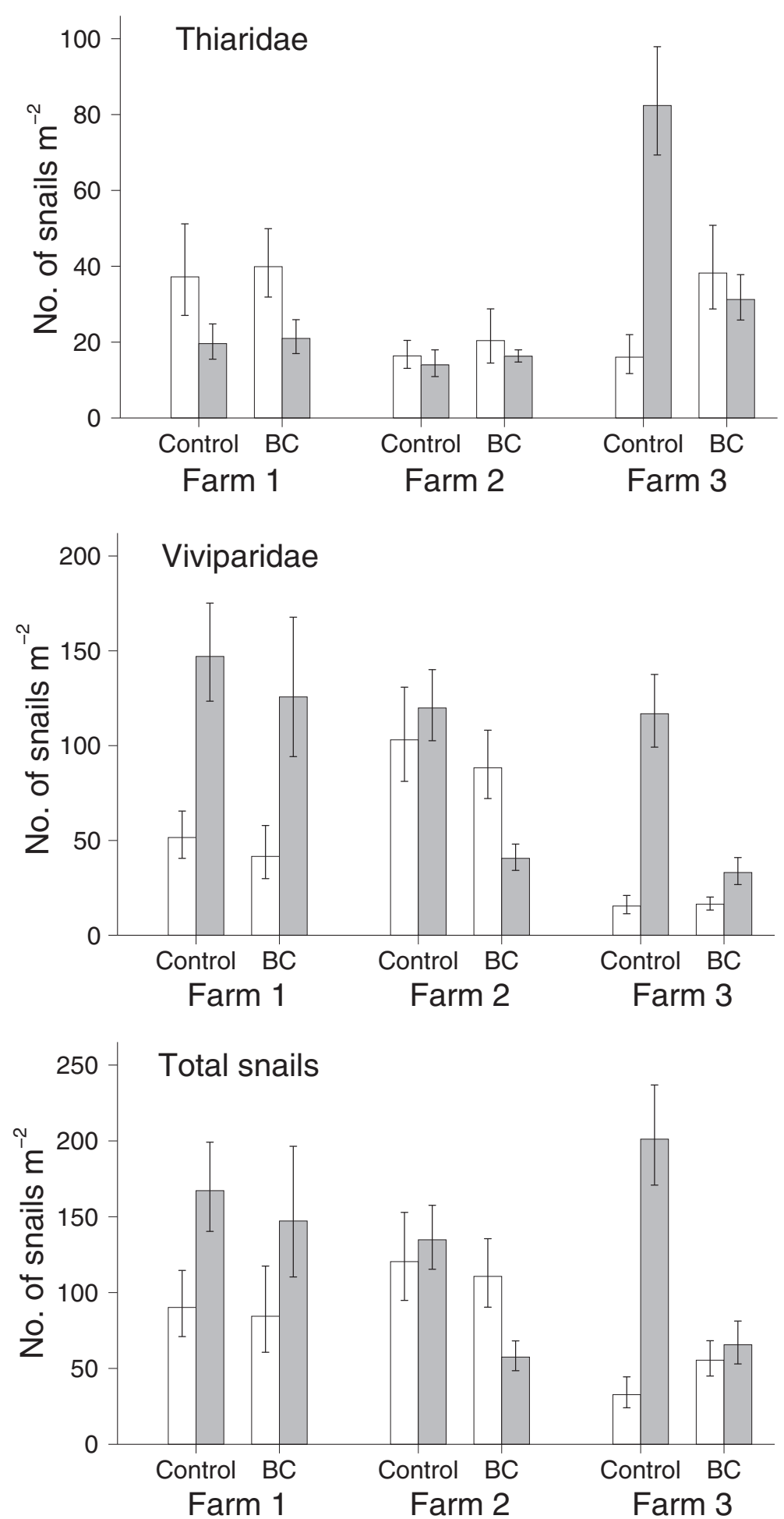

Figure 1 Snail density in nursery ponds before (open column) stocking with fry and with 2 black carp specimens (BC) or only fry (control) and 3 months later (shaded column) in three households in Nam Dinh Province, Vietnam 2011. Error bars show 95\% confidence limits. 


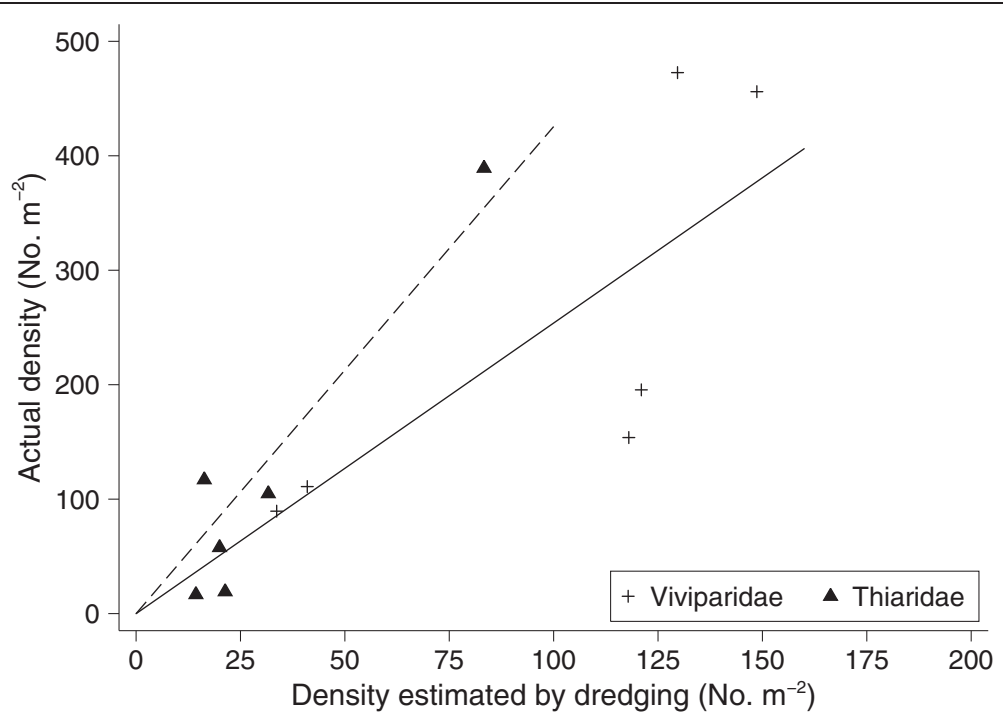

Figure 2 Density of viviparid and thiarid snails in nursery pond in Nam Dinh estimated using 2 different sampling methods.

be estimated as average weight $(750 \mathrm{~g} /$ fish) consuming $20 \%$ of their body weight per day for 69 days, which would amount to $20.7 \mathrm{~kg}$.

\section{Stomach of black carp content}

All stomachs of the black carp were found to be empty. Unfortunately, against prior agreement, farmers decided to remove the juvenile fishes from the nursery ponds about 2 days prior to our final sampling, so we could not collect data to compare juvenile fish production and the seining required to capture the juvenile carps could have disturbed the black carp.

\section{Discussion}

The results show that black carp effectively locate snails and consume large amounts of snails. Thus, in the semifield experiment, the pond was virtually cleared of snails. The number of snails added in the experimental pond was clearly less than the potential consumption possible by the fishes and snails venturing outside the exclosures would likely be eaten. The effect was less clear in the nursery ponds in Nam Dinh. Although total snail density increased during the experimental time in both control and intervention ponds, the density of thiarid snails declined in the intervention ponds. Stocking density of black carp was high in the experimental pond, while it was probably too low in the nursery ponds to have a more significant impact on snail population density during one nursing cycle (9 weeks). Nico et al. [30] reported that small black carp can consume a snail weight equivalent of up to $20 \%$ of its body weight per day, but big fish were satiated at about $6 \%$. A rough estimation of the minimum total weight of snails needed for the 15 black carp
(700 - 1500g) kept in the experimental would be: 15 fishes $\mathrm{x}(700$ to $1500 \mathrm{~g}) \times 6 \% \times 90$ days $=56.7-121.5 \mathrm{~kg}$.

The standing crop of snails in the nursery ponds can be high and could easily exceed the consumption capacity of the two black carp specimens and recruitment to snail populations is also high during the study period. Experiments using black carp to control Planorbella trivolvis (Say, 1817) in catfish ponds did not result in significant decline in density as compared to control ponds until 6 months after the introduction of the black carp to the ponds [35]. The farmers in Vietnam normally introduce between 1-5 specimens of black carp per pond depending on pond size (180 - 500 square meters) and density of snails [42]. This stocking density was applied in the nursery ponds of our experiment, while in the semifield trial, it was 2 and 4 times higher, respectively. Zobel (1975) quoted in [30] gave a formula to calculate the number of black carp required for stocking in different types or sizes of water bodies: $M=\{[a \times(b \times 10,000)] / P\} \times 0.023$, where $\mathrm{M}=$ stocking density of black carp (fish per hectare), $\mathrm{a}=$ the number of molluscs per square meter, $\mathrm{b}=$ surface area in hectares, $10,000=$ number of square meters per hectare, $\mathrm{P}=$ daily consumption of molluscs by black carp, and 0.023 is a constant. However, the value of a and P could be changing with various factors, e.g. season of the year, temperature, prey species composition etc.

In the Red River Delta, black carp is normally used only in grow-out ponds and the purpose is to utilize the snail biomass for fish production [42]; black carp is a valued species for human consumption. Others do it to control snails either because they believe that snails compete with the fishes for food resources or to reduce the nuisance that pointed snail shells constitute when barefooted farmers manage emptied ponds prior to 
restocking (personal communication with farmers). If snail populations decrease, farmers with black carp may supply snails collected from other habitats as food for the black carp. Thus maintenance of black carp could become a risk factor for infections in fish if the snails collected from small canals or rice fields include FZT intermediate hosts, because infection levels in intermediate host snails in these habitats can be high [26].

In the nursery ponds, the most pronounced reduction in density was observed for the thiarid snails. Hung et al. [43] showed that even small black carp can handle fairly large specimens of $M$. tuberculata, while larger black carp specimens consumed relatively more viviparid snails and this is probably due to the difference in shell shape, i.e. M. tuberculata has a much smaller shell diameter than the viviparid snails. Black carp have a relatively small mouth and the size of prey that it can handle depends on its gape size. Shelton et al. [44] conducted experiments with various species and sizes of snails by using black carp as a predator and found that fish between 100 and $500 \mathrm{~mm}$ (total length) with gape width from 7 to $25 \mathrm{~mm}$ could consume snails measuring 7-17 $\mathrm{mm}$ in shell diameter. Another reason could be that the shell strength differs among snail species $[45,46]$. Optimal foraging strategy predicts that molluscivore fishes chose their prey partly depending on a low cost/benefit ratio as measured from crush resistance of the snail shell relative to weight of snail tissue gained [47] and partly on the abundance of snail species [48,49].

The stomachs of the black carp were empty both in the semi field experiment and in the nursery ponds. For the fish from the semi field trial this could be explained by the fact that the fish almost eliminated snails from the pond, while for the nursery ponds farmers had seined all juvenile fishes immediately before termination of experiments and this could have disturbed the black carp. Data reviewed by Nico et al. [30] showed that shell fragments are often found in black carp stomachs. During laboratory feeding trials, we, however, observed that the black carp often spat out the crushed snail and then picked up the soft parts thus reducing the amount of shell material ingested. It has been shown that ingestion of shell material is energetically expensive [50].

The implications of our findings is that black carp can control snails in fish ponds, but the standing crop of snails in nursery ponds can be too high for a few black carp specimens to reduce it to a level, where transmission of FZTs is significantly affected during the relatively short nursing cycle (about 9 weeks). It may therefore be necessary to reduce snail densities prior to stocking the nursery ponds with fish fry using pond management, for example through mud and vegetation removal [38]. An alternative would be to increase the stocking density of the black carp considerably. Although overall there is a relationship between infection levels in fishes and either the density of snails or infected snails in nursery ponds, infection levels in fishes can be high even when snail density in ponds is very low [51]. This is probably because nursery ponds often are supplied with water from nearby canals where the density of intermediate hosts and infection levels with FZT in these often is high. It seems that these canals can be important for transmission in ponds depending on water exchange between canals and ponds. Many ponds have a tube connecting it to a canal so that water can go in or out of the pond depending on where water level is highest. The tube has a mesh at both ends preventing passage of fish but cercariae and possibly snails could pass. The tube can be closed by the farmer. Species of the Bithyniidae (especially Bithynia fuchsiana and Parafossarulus manchouricus), which are intermediate hosts of Clonorchis sinensis in this area, can be very abundant especially in small canals [26]. Thus experiments should be conducted to see whether these snails could be controlled in small canals using black carp; this, however, requires close community cooperation because the small canals, support thriving fish populations and are often fished by people (personal observations). The black carp used for snail control should be small specimens, because due to gape limitation they will feed primarily on species of the Thiaridae and Bithynidae, which are important as intermediate hosts for the FZT, but of course they also would feed on juvenile specimens of species of the Viviparidae and Ampullaridae.

Although FZT infections in people can be treated medically [17] the high level of infection in domestic animals like dogs, cats and pigs [52,53] means that transmission persists after treatment of people. Including domestic animals in treatment campaigns would be a major challenge. At least for intestinal FZTs, the short life cycle [54] means that animals should be treated at frequency that is not logistically feasible. Hence farm/ pond management [38] including stocking of ponds with black carp could well prove the major intervention to prevent infections in fish and people.

\section{Conclusions}

Black carp can be used for control of snail populations in nursery ponds but pond preparation prior to stocking should reduce snail population density to make it possible for a few black carp specimens to prevent snail populations from building up.

\section{Competing interests}

The authors declared that they have no competing interest.

\section{Authors' contributions}

$\mathrm{NMH}, \mathrm{NVD}, \mathrm{RJS} \mathrm{Jr}$, HM were involved in development of the study design. $\mathrm{NMH}, \mathrm{HM}$ performed the experiments. Data analyses were carried out by $\mathrm{NMH}$ and $\mathrm{HM}$. All authors read and approved the manuscript. 


\section{Acknowledgements}

We would like to thank the three farmers from Hai Quang commune in Nam Dinh for their cooperation. We are grateful to Research Institute for Aquaculture No 1 for allowing us to use the experimental pond and the FIBOZOPA project for assistance and hospitality. This study was funded by DBL-Centre for Health Research and Development, Department of Veterinary Disease Biology, Faculty of Health and Medical Sciences, University of Copenhagen.

\section{Author details}

'Department of Parasitology, Institute of Ecology and Biological Resources, Vietnam Academy of Science and Technology, 18 Hoang Quoc Viet, Hanoi, Vietnam. ${ }^{2}$ Ecosystem Science and Management, Pennsylvania State University, 432 Forest Resources Building, University Park, PA 16802-4300, USA. ${ }^{3}$ Centre for Health Research and Development, Department of Veterinary Disease Biology, Faculty of Health and Medical Sciences, University of Copenhagen, Thorvaldsensvej 57, Frederiksberg C 1871, Denmark.

Received: 8 January 2013 Accepted: 8 May 2013

Published: 16 May 2013

\section{References}

1. Chai JY, Murrell KD, Lymbery AJ: Fish-borne parasitic zoonoses: status and issues. Int J Parasitol 2005, 35:1233-1254.

2. Sripa B, Sithithaworn P, Sirisinha S: Opisthorchis viverrini and opisthorchiasis. The 21st century review. Acta Trop 2003, 88:169-170.

3. Sen-Hai Y, Mott KE: Epidemiology and morbidity of food-borne intestinal trematode infections.; 1994. WHO/SCHISTO/94.108 1994 26pp.

4. Mas-Coma S, Bargues MD: Human liver flukes: a review. Res Rev Parasitol 1997, 57(Suppl 3-4):145-218.

5. Fried B, Graczyk TK, Tamang L: Food-borne intestinal trematodiasis in humans. Parasitol Res 2004, 93:159-170.

6. Phan TV, Ersbøll AK, Nguyen VK, Madsen H, Dalsgaard A: Farm-level risk factors for fish-borne zoonotic trematode infection in integrated small-scale fish farms in northern Vietnam. PLoS Negl Trop Dis 2010, 4(Suppl 7):e742.

7. Toledo R, Esteban JG, Fried B: Immunology and pathology of intestine trematodes in their definitive hosts. Adv Parasitol 2006, 63:285-365.

8. Le NT: Trematode parasites in humans and animals. In: Fauna of Vietnam. Science and Technical Publishing House; 2000 (in Vietnamese).

9. De NV, Murrell KD, Cong LD, Cam PD, Chau LV, Toan ND, Dalsgaard A: The food-borne trematodes zoonoses of Vietnam. Southeast Asian J Trop Med Public Health 2003, 34:12-34.

10. Phan TV, Ersbøll AK, Te BQ, Hang NT, Murrell KD, Dalsgaard A: Fish-borne zoonotic trematodes in cultured and wild-caught freshwater fish from the Red river delta, Vietnam. Vector Borne Zoonotic Dis 2010, 10:861-866.

11. Dung DT, De NV, Waikagul J, Dalsgaard A, Chai JY, Sohn WM, Murrell KD: Fishborne zoonotic intestinal trematodes, Vietnam. Emerg Infect Diseases 2007, 13:1828-1833.

12. Lima dos Santos CAM, Howgate P: Fishborne zoonotic parasites and aquaculture. A review. Aquaculture 2011, 318(Suppl 3-4):253-261.

13. Choi $\mathrm{BI}$, Han JK, Hong ST, Lee KH: Clonorchiasis and cholangiocarcinoma: etiologic relationship and imaging diagnosis. Clin Microbiol Rev 2004, 17(Suppl 3):540-552.

14. Natthawut K, Soraya JK, Prasit P, Banchob S: Opisthorchis viverrini: the carcinogenic human liver fluke. World I Gastroenterol 2008, 14(Suppl 5):666-674.

15. International Agency for Research on Cancer: IARC monograph on the evaluation of carcinogenic risks to humans. Biological agents. Int Agency Res Cancer 2012, 100B:341-370.

16. Lun ZR, Gasser RB, Lai DH, Li AX, Zhu XQ, Yu XB, Fang YY: Clonorchiasis: a key foodborne zoonosis in China. Lancet Infect Dis 2005, 5(Suppl 1):31-41.

17. Keiser J, Utzinger J: Emerging FoodborneTrematodiasis. Emerg Infect Diseases 2005, 11(Suppl 10):1507-1514.

18. Chai JY: Intestinal flukes. In Food-borne parasitic zoonoses: fish and plantborne parasites. Edited by Murrell KD, Fried B. New York: Springer Science; 2007:53-116.

19. Fredensborg BL, Mouritsen KN, Poulin R: Impact of trematodes on host survival and population density in the intertidal gastropod Zeacumantus subcarinatus. Mar Ecol Prog Ser 2005, 290:109-117.
20. Jensen $T$, Jensen $K T$, Mouritsen KN: The influence of the trematode Microphallus claviformis on two congeneric intermediate host species (Corophium): infection characteristics and host survival. J Exp Mar Biol Ecol 1998, 227:35-48.

21. Sommerville C: The pathology of Haplorchis pumilio (Looss, 1896) infections in cultured tilapias. J Fish Dis 1982, 5(Suppl 3):243-250.

22. Mitchell AJ, Salmon MJ, Huffman DG, Goodwin AE, Brandt TM: Prevalence and pathogenicity of a heterophyid trematode infecting the gills of an endangered fish, the fountain darter, in two central Texas spring-fed rivers. J Aquat Anim Health 2000, 12(Suppl 4):283-289.

23. Barber I, Hoare D, Krause J: Effects of parasites on fish behaviour: a review and evolutionary perspective. Rev Fish Biol Fish 2000, 10:131-165.

24. Tai MV, Thuyet BD, Nam TH, Binh ND, Chuong NQ: Aquaculture practices in Nam Dinh province. Tu Son, Bac Ninh: Fibozopa project Research Institute of Aquaculture No. 1; 2004.

25. Hop LT: Programs to improve production and consumption of animal source foods and malnutrition in Vietnam. J Nutr 2003, 133(Suppl 2):4006S-4009S.

26. Dung BT, Madsen $H$, The DT: Distribution of freshwater snails in family-based VAC ponds and associated waterbodies with special reference to intermediate hosts of fish-borne zoonotic trematodes in Nam Dinh provinces, Vietnam. Acta Trop 2010, 116:15-23.

27. Phan TV, Ersbøll AK, Nguyen TT, Nguyen KV, Nguyen HT, Murrell D, Dalsgaard A: Freshwater aquacuclture nurseries and infection of fish with zoonotic trematodes, Vietnam. Emerg Infect Diseases 2010, 16(Suppl 12):1905-1909.

28. Thien PC, Dalsgaard A, Nhan NT, Olsen A, Murrell KD: Prevalence of zoonotic trematode parasites in fish fry and juveniles in fish farms of the Mekong Delta, Vietnam. Aquaculture 2009, 295:1-5.

29. Thien PC, Dalsgaard A, Thanh BN, Olsen A, Murrell KD: Prevalence of fish-borne zoonotic parasites in important cultured fish species in the Mekong Delta, Vietnam. Parasitol Res 2007, 101:1277-1284

30. Nico LG, Williams JD, Jelks HL: Black Carp - Biological synopsis and risk assessment of an introduced fish. Maryland: American Fisheries Society Special Publication; 2005

31. Ben-Ami F, Heller J: Biological control of aquatic pest snails by the black carp Mylopharyngodon piceus. Biol Control 2001, 22(Suppl 2):131-138.

32. Ledford JJ, Kelly AM: A comparison of black carp, redear sunfish and blue catfish as biological control of snail population. N Am J Aquacult 2006, 68:339-347.

33. Mochida O: Spread of freshwater Pomacea snails (Pilidae, Mollusca) from Argentina to Asia. Micronesica 1991, 3(Suppl):41-62.

34. Halwart M: The golden apple snail Pomacea canaliculata in Asian rice farming systems: present impact and future threat. Int J Pest Manage 1994, 40(Suppl 2):199-206.

35. Venable DL, Gaude AP, Klerks PL: Control of the trematode Bolbophorus confusus in channel catfish Ictalurus punctatus ponds using salinity manipulation and polyculture with black carp Mylopharyngodon piceus. J World Aquacult Soc 2000, 31:158-166.

36. Slootweg R: Snail control by fish: an explanation for its failure. NAGA, The ICLARM Quarterly 1995, 18(Suppl 4):16-19.

37. Hung NM: Use of black carp, Mylopharyngodon piceus (Cyprinidae), for control of intermediate host snails for fishborne zoonotic trematodes in Vietnamese aquaculture ponds, Ph.D. thesis. University of Copenhagen: Faculty of Health and Medical Sciences; 2013.

38. Clausen JH, Madsen H, Murrell KD, Van PT, Ha NTT, Dung TD, Anh NTL, Hung NM, Dalsgaard A: Prevention and control of Fish-borne zoonotic trematodes in Fish nurseries, Vietnam. Emerg Infect Diseases 2012, 18 (Suppl 9):1438-1445.

39. Thanh DN: Identification of freshwater invertebrates in Northern Vietnam. Vietnamese: Science and Technology press; 1980:440-490.

40. Brandt RAM: The non-marine aquatic mollusca of Thailand. Arch Molluskenkd 1974, 105:1-423.

41. Hilbe JM: Negative binomial regression. Cambridge: Cambridge University Press; 2008.

42. Van KV, Tuyet TA, Hoai TD, Dung KT: Initial results of black carp monoculture in ponds in Haiduong province. J Sci Dev 2010, 8(Suppl 3):481-487 (in Vietnamese).

43. Hung NM, Stauffer JR Jr, Madsen H: Prey species and size choice of the molluscivorous fish, black carp (Mylopharyngodon piceus). J Freshwat Ecol. In press. 
44. Shelton WL, Soliman A, Rothbard S: Experimental observations on feeding biology of black carp, Mylopharyngodon piceus. Isr J Aquacult/Bamidgeh 1995, 47:59-67.

45. Zuschin M, Stanton RJ Jr: Experimental measurement of shell strength and its taphonomic interpretation. Palaios 2001, 16:161-170.

46. Cote J, Rakocinsky CF, Randall TA: Feeding efficiency by juvenile blue crabs on two common species of micrograzer snails. J Exp Mar Biol Ecol 2001, 264:189-208.

47. Evers BN, Madsen H, Stauffer JR Jr: Crush-resistance of soft-sediment gastropods of Lake Malawi: implications for prey selection by molluscivorous fishes. J Freshwat Ecol 2011, 26:85-90.

48. Stauffer JR, Arnegard ME, Cetron M, Sullivan JJ, Chitsulo LA, Turner GF, Chiotha S, McKaye KR: Controlling vectors and hosts of parasitic diseases using fishes, a case history of schistosomiasis in Lake Malawi. Bioscience 1997, 47(Suppl 1):41-49.

49. Brodersen J, Madsen $\mathrm{H}$ : The effect of calcium concentration on the crushing resistance, weight and size of Biomphalaria sudanica (Gastropoda: Planorbidae). Hydrobiologia 2003, 490:181-186.

50. Hoogershood RJC: The adverse effects of shell ingestion for molluscivorous cichlids, a constructional morphological approach. Neth J Zool 1987, 37:277-300.

51. Clausen JH, Madsen H, Murrell KD, Phan TV, Manh HN, Viet KN, Dalsgaard A: Relationship between snail population density and infection status of snails and fish with zoonotic trematodes in Vietnamese carp nurseries. PLoS Negl Trop Dis 2012, 6:e1945.

52. Anh NTL, Phuong NT, Johansen MV, Murrell KD, Van PT, Dalsgaard A, Thu $L T$, Thamsborg SM: Prevalence and risks for fishborne zoonotic trematode infections in domestic animals in a highly endemic area of North Vietnam. Acta Trop 2009, 112:198-203.

53. Lin RQ, Tang JD, Zhou DH, Song HQ, Huang SY, Chen JX, Chen MX, Zhang $H$, Zhu XQ, Zhou XN: Prevalence of Clonorchis sinensis infection in dogs and cats in subtropical southern China. Parasit Vectors 2011, 4:180.

54. Nissen S, Thamsborg SM, Kania PW, Leifsson PS, Dalsgaard A, Johansen MV: Population dynamics and host reactions in young foxes following experimental infection with the minute intestinal fluke, Haplorchis pumilio. Parasit Vectors 2013, 6:4.

doi:10.1186/1756-3305-6-142

Cite this article as: Hung et al.: Use of black carp (Mylopharyngodon piceus) in biological control of intermediate host snails of fish-borne zoonotic trematodes in nursery ponds in the Red River Delta, Vietnam.

Parasites \& Vectors 2013 6:142

\section{Submit your next manuscript to BioMed Central and take full advantage of:}

- Convenient online submission

- Thorough peer review

- No space constraints or color figure charges

- Immediate publication on acceptance

- Inclusion in PubMed, CAS, Scopus and Google Scholar

- Research which is freely available for redistribution 